\title{
DIFFERENTIAL ALLELOPATHIC EXPRESSION OF DIFFERENT PLANT PARTS OF ACHILLEA BIEBERSTEINII
}

\author{
SAEID ABu-Romman * \\ Department of Biotechnology, Faculty of Agricultural Technology, Al-Balqa' Applied University, \\ Al-Salt 19117, Jordan
}

(Received: September 7, 2015; accepted: October 14, 2015)

\begin{abstract}
Achillea biebersteinii (Asteraceae) is a perennial medicinal plant and has a wide distributional range in the Mediterranean region. The present study investigated the inhibitory effects of different plant parts of A. biebersteinii on germination characteristics and seedling growth of wild barley (Hordeum spontaneum). Water extracts were prepared by incubating separately five grams of dried powder of roots, stems, leaves and flowers of A. biebersteinii in $100 \mathrm{ml}$ of distilled water for $24 \mathrm{~h}$ and distilled water was used as the control. The water extracts from different plant parts of $A$. biebersteinii differed in their effects on the germination and seedling growth of wild barley. Water extracts prepared from leaves and flowers were more suppressive to germination of wild barley than root and stem extracts. The maximum inhibition in radical and plumule growth of germinating caryopses and in root and shoot growth of greenhouse-grown wild barley was recorded for leaf extract followed by flower extract. The lowest $\mathrm{Chl} \mathrm{a}, \mathrm{Chl} \mathrm{b}$ and total chlorophyll and protein contents were resulted after exposure to leaf extracts. According to these results, the inhibitory effects of different $A$. biebersteinii plant parts can be arranged in the order: leaf $>$ flower $>$ stem $>$ root.
\end{abstract}

Keywords: Achillea biebersteinii - Allelopathy - chlorophyll pigments - germination - Hordeum spontaneum - seedling growth - water extract

\section{INTRODUCTION}

Allelopathy is a common phenomenon in nature and can be defined as the inhibitory or stimulatory effects of one plant species on another one through the release of secondary metabolites (known as allelochemicals) that escape into the environment [35]. These allelochemicals are released into the environment via root exudation, leaching by rains, decomposition of plant materials and volatilization [42]. Allelochemicals are present in almost all plant species and their different parts [43]. Due to their natural origin, allelochemicals are currently applied in organic agricultural practices as a biological tool to control weed instead of using synthetic herbicides [18, 22].

\footnotetext{
*E-mail address: ssadroman@yahoo.com
} 
Several allelochemicals were reported to impose potential phytotoxicity to physiological processes in other plants [8], affecting growth, survival and reproduction [20, 43]. However, allelopathic plants can also be affected negatively by their own allelochemicals, a process known as autointoxication [25]. Allelochemicals produced by plants are reported to interfere with the surrounding environment of other plants which in turn result in alteration in soil biotic factors such as soil microbial activity, or abiotic factors such as soil acidity and fertility, hence playing a significant role in agroecosystems $[9,11,24]$.

Besides their use in natural remedies, herbal and medicinal plants are attracting great attention in the community of plant science [2]. Since these plants contain high levels of bioactive phytochemicals, the phenomenon of allelopathy has been reported in several medicinal plants $[3,23,40]$.

Achillea biebersteinii (Asteraceae) is one of the most predominant medicinal Achillea species in the Mediterranean region [46]. In folk medicine, A. biebersteinii has been used as a carminatives and in the treatment of intestinal colic and dysentery [5]. Moreover, antimicrobial and anti-inflammatory activities were recorded for this species [6]. For medicinal purposes, essential oils have been purified from A. biebersteinii and were found to be rich in ascaridol, $p$-cymene, carvenone oxide and camphor $[1,7,41]$.

Recently, we have shown that leaf extracts of A. biebersteinii impose allelochemical stress on pepper plants [3]. The aim of this study was to further investigate the effects of aqueous extracts from the different parts of A. biebersteinii (root, stem, leaf and flower) on seed germination and early growth of wild barley (Hordeum spontaneum).

\section{MATERIALS AND METHODS}

\section{Preparation of A. biebersteinii water extracts}

Whole mature plants of A. biebersteinii were collected at the flowering stage in July, 2012 from natural stands found in Amman, Jordan $\left(31^{\circ} 57^{\prime} \mathrm{N}\right.$ latitude; $35^{\circ} 65^{\prime} \mathrm{E}$ longitude; $920 \mathrm{~m}$ above sea level). Plants roots, stems, leaves and flowers were separated and dried at $45{ }^{\circ} \mathrm{C}$ until the weight was constant. Oven-dried tissues were ground to a fine powder by a blender. Five grams of each plant part was separately extracted in $100 \mathrm{ml}$ distilled water (5\% extract) for $24 \mathrm{~h}$ at room temperature using an orbital shaker set at $120 \mathrm{rpm}$. The extracts were then filtered through three layer of cheese cloth to remove the tissue debris and centrifuged at $3500 \times \mathrm{g}$ for $30 \mathrm{~min}$. The resulting supernatants were filtered through Whatmann No. 1 filter papers. The $\mathrm{pH}$ values of all extracts including distilled water (control) were adjusted to 6.0 with $1 \mathrm{~N} \mathrm{HCl}$ using a $\mathrm{pH}$ meter. The osmotic potential (OP) of all extracts was calculated using the following equation [28]:

$$
\mathrm{OP}=\text { Electrical conductivity } \times-0.36
$$


The OP values of all extracts were found to be in the range of -0.087 to -0.15 , and under such values, no significant growth inhibition was reported [26]. All extracts were kept refrigerated at $4{ }^{\circ} \mathrm{C}$.

\section{Effects of $\mathrm{A}$. biebersteinii water extracts on germination and early seedling growth of wild barley}

Wild-barley (Hordeum spontaneum) caryopses were surface-sterilized in 2\% sodium hypochlorite solution for $5 \mathrm{~min}$, then washed four times in distilled water and dried between two filter papers. The sterilized caryopses were soaked in distilled water (control) and respective extract solutions from each plant parts of $A$. biebersteinii for $3 \mathrm{~h}$. After that, 20 uniform seeds of each control and treatment were evenly placed on Petri plates lined with four layers of Whatmann No. 1 filter papers. Initially, filter papers were moistened with $15 \mathrm{ml}$ of respective extract solution in treatment and distilled water in control and Petri plates were incubated in a growth incubator at $24 \pm 2{ }^{\circ} \mathrm{C}$. A $5 \mathrm{ml}$ of extract solution and distilled water were added on alternate days. Germination was recorded daily until eight days. Caryopses were considered germinated after the emergent radical had protruded beyond the seed coat by at least $1 \mathrm{~mm}$. After 8 days, final germination percentage, radical and plumule lengths and their dry weights were recorded. Treatments were arranged in a completely randomized design with eight replications and the experiment was repeated three times.

\section{Effects of A. biebersteinii water extracts on seedling growth of wild barley}

Wild-barley caryopses were sterilized as mentioned above. Four caryopses were planted at equal distance in experimental pots $(15 \mathrm{~cm}$ in diameter, $25 \mathrm{~cm}$ in height) filled with homogenous soil and pots were placed in the greenhouse. Each pot was irrigated every two days with $100 \mathrm{ml}$ of graded concentration of extract solution according to the treatments. The pots irrigated with distilled water were taken as control. After four weeks, data were recorded for root and shoot dry weights, chlorophyll pigments and protein content. Treatments were arranged in a randomized complete block design with six replications and the experiment was repeated three times.

\section{Determination of chlorophyll content}

Chlorophyll pigments from leaf tissues were extracted in $80 \%$ acetone for $24 \mathrm{~h}$ at $4{ }^{\circ} \mathrm{C}$, and the resulting extracts were centrifuged at $3500 \times \mathrm{g}$ for $5 \mathrm{~min}$. The absorbance of the extracts was measured spectrophotometrically at 645 and $664 \mathrm{~nm}$. Amounts of chlorophyll a (Chl a) and chlorophyll b $(\mathrm{Chl} b)$ were quantified according to the following equations [27]: 


$$
\begin{aligned}
& \text { Chl a }(\mathrm{mg} / \mathrm{g} \mathrm{FW})=11.75 \times \mathrm{A}_{663}-2.35 \times \mathrm{A}_{645} \\
& \text { Chl b }(\mathrm{mg} / \mathrm{g} \mathrm{FW})=18.61 \times \mathrm{A}_{645}-3.96 \times \mathrm{A}_{663}
\end{aligned}
$$

After calculation of $\mathrm{Chl}$ a and $\mathrm{Chl} b$ values, total chlorophyll $(\mathrm{Chl} \mathrm{a}+\mathrm{Chl} \mathrm{b})$ values were determined.

\section{Determination of protein content}

Leaf tissues of barley seedlings were ground in liquid nitrogen into fine powder. About $300 \mu \mathrm{l}$ of total protein extraction buffer $(100 \mathrm{mM} \mathrm{NaCl} ; 50 \mathrm{mM}$ Tris-HCl, $\mathrm{pH}$ $7.5 ; 0.5 \%(\mathrm{v} / \mathrm{v})$ Triton X-100; $10 \mathrm{mM} \beta$-Mercaptoethanol; $2 \mu \mathrm{l} \cdot \mathrm{ml}^{-1}$ Protease inhibitor mix) was added to the powder in a microfuge tube and the mixture was homogenized. The cell debris was pelleted in a centrifuge at $12,000 \mathrm{rpm}$ and $4{ }^{\circ} \mathrm{C}$ for $10 \mathrm{~min}$. Protein concentration in barley seedlings was estimated by a colorimetric assay according to Bradford [12]. To measure the concentration of proteins in leaf extract, $800 \mu 1$ of an appropriate dilution of the protein extracts was mixed with $200 \mu \mathrm{l}$ of Bradford reagent and incubated for $15 \mathrm{~min}$ at room temperature. The protein absorbance was recorded at $595 \mathrm{~nm}$, and protein concentration was determined by plotting the $\mathrm{OD}_{595}$ against BSA standard curve.

\section{Statistical analysis}

The data were subjected to one-way analysis of variance; differences between treatment means were determined by the least significant difference (LSD) test at the $5 \%$ level of probability. Data were analyzed using SAS program [36].

\section{RESULTS}

The allelopathic potential of water extracts of root, stem, leaf and flower from A. biebersteinii was tested on the germination and seedling growth of wild barley.

Final germination percentage of wild barley was significantly reduced when caryopses were subjected to stem, leaf, and flower extracts of A. biebersteinii. The germination percentage was reduced by $17.6 \%, 34.1$ and $37.4 \%$ with stem, flower and leaf extracts (Table 1). However, applying root extracts showed no effects on germination percentage of wild barley.

The germination rate was significantly influenced by A. biebersteinii water extracts. The germination of wild-barley caryopses was delayed as a response of all extracts. The germination rate was 8.69 caryopses /day under the control conditions (distilled water). While a maximum reduction in germination rate $(53 \%)$ arised from leaf extract followed by flower extract with an average reduction of $48.8 \%$. 
Table 1

Allelopathic effect of Achillea biebersteinii water extracts on germination and early seedling growth of wild barley

\begin{tabular}{|l|c|c|c|c|c|c|}
\hline \multicolumn{1}{|c|}{ Treatments } & $\begin{array}{c}\text { Germination } \\
(\%)\end{array}$ & $\begin{array}{c}\text { Germination } \\
\text { rate }\end{array}$ & $\begin{array}{c}\text { Radical } \\
\text { length }(\mathrm{cm})\end{array}$ & $\begin{array}{c}\text { Plumule } \\
\text { length }(\mathrm{cm})\end{array}$ & $\begin{array}{c}\text { Radical dry } \\
\text { weight (mg) }\end{array}$ & $\begin{array}{c}\text { Plumule dry } \\
\text { weight }(\mathrm{mg})\end{array}$ \\
\hline Control & $96.91 \mathrm{a}$ & $8.69 \mathrm{a}$ & $10.09 \mathrm{a}$ & $7.11 \mathrm{a}$ & $7.12 \mathrm{a}$ & $8.88 \mathrm{a}$ \\
\hline Root extract & $87.26 \mathrm{ab}$ & $5.97 \mathrm{~b}$ & $8.32 \mathrm{~b}$ & $5.83 \mathrm{~b}$ & $6.06 \mathrm{~b}$ & $7.97 \mathrm{ab}$ \\
\hline Stem extract & $79.81 \mathrm{~b}$ & $5.61 \mathrm{~b}$ & $6.79 \mathrm{c}$ & $5.47 \mathrm{~b}$ & $4.04 \mathrm{c}$ & $7.30 \mathrm{bc}$ \\
\hline Leaf extract & $60.71 \mathrm{c}$ & $4.07 \mathrm{c}$ & $4.64 \mathrm{~d}$ & $3.22 \mathrm{c}$ & $2.63 \mathrm{~d}$ & $5.04 \mathrm{~d}$ \\
\hline Flower extract & $63.90 \mathrm{c}$ & $4.45 \mathrm{bc}$ & $6.12 \mathrm{c}$ & $4.68 \mathrm{~b}$ & $3.15 \mathrm{~d}$ & $6.78 \mathrm{c}$ \\
\hline
\end{tabular}

Means within each column followed by the same letter are not significantly different at $P \leq 0.05$, according to LSD test.

Radical and plumule growth were significantly and negatively affected by A. biebersteinii water extracts (Table 1 ). Leaf extracts resulted in a significantly shorter radicals $(4.64 \mathrm{~cm})$ and plumule $(3.22 \mathrm{~cm})$ of germinating wild-barley caryopses as compared to other extracts. Stem and flower extracts resulted in almost the same level of inhibition in radical length. While, root, stem and flower extracts resulted in almost the same plumule length. Radical dry weight was reduced by 15, 43, 55.7 and $63 \%$ when wild-barley caryopses were treated with root, stem, flower and leaf extracts of A. biebersteinii, respectively. Plumule dry weight was found to be less affected by A. biebersteinii water extracts. Leaf extracts was the most inhibitory to plumule dry weight with a reduction percentage of $43 \%$ (Table 1).

Water extracts of $A$. biebersteinii caused significant alterations in root and shoot dry weights of wild-barley seedlings. As shown in Table 2, root dry weight was decreased to $53.7 \%$ of the control when seedlings were treated with leaf extracts of A. biebersteinii. Shoot dry weight of wild barley was not significantly affected by treatment with root extracts. While all other extracts were found to decrease shoot dry weight. Leaf extract was shown to reduce shoot dry weight to $24 \%$.

Table 2

Allelopathic effect of Achillea biebersteinii water extracts on root and shoot dry weights of wild barley seedlings

\begin{tabular}{|l|c|c|}
\hline \multicolumn{1}{|c|}{ Treatments } & Root dry weight (mg) & Shoot dry weight (mg) \\
\hline Control & $32.02 \mathrm{a}$ & $260.9 \mathrm{a}$ \\
\hline Root extract & $24.21 \mathrm{~b}$ & $244.1 \mathrm{ab}$ \\
\hline Stem extract & $21.86 \mathrm{bc}$ & $231.5 \mathrm{bc}$ \\
\hline Leaf extract & $14.83 \mathrm{~d}$ & $198.2 \mathrm{c}$ \\
\hline Flower extract & $18.74 \mathrm{~cd}$ & $211.1 \mathrm{c}$ \\
\hline
\end{tabular}

Means within each column followed by the same letter are not significantly different at $P \leq 0.05$, according to LSD test. 
Table 3

Allelopathic effect of Achillea biebersteinii water extracts on chlorophyll pigments and protein contents of wild barley seedlings

\begin{tabular}{|l|c|c|c|c|}
\hline \multicolumn{1}{|c|}{ Treatments } & Chlorophyll a & Chlorophyll b & Total chlorophyll & Protein content \\
\hline Control & $9.30 \mathrm{a}$ & $6.29 \mathrm{a}$ & $15.59 \mathrm{a}$ & $16.19 \mathrm{a}$ \\
\hline Root extract & $7.28 \mathrm{~b}$ & $6.04 \mathrm{a}$ & $13.32 \mathrm{~b}$ & $15.10 \mathrm{a}$ \\
\hline Stem extract & $7.04 \mathrm{~b}$ & $5.89 \mathrm{ab}$ & $12.93 \mathrm{~b}$ & $12.56 \mathrm{~b}$ \\
\hline Leaf extract & $5.83 \mathrm{c}$ & $4.66 \mathrm{c}$ & $10.49 \mathrm{c}$ & $9.44 \mathrm{c}$ \\
\hline Flower extract & $6.95 \mathrm{~b}$ & $5.41 \mathrm{~b}$ & $12.36 \mathrm{~b}$ & $10.20 \mathrm{c}$ \\
\hline
\end{tabular}

Means within each column followed by the same letter are not significantly different at $P \leq 0.05$, according to LSD test.

The effect of water extracts of $A$. biebersteinii on chlorophyll pigments was also examined. The amount of $C h l a$ was significantly affected by the different extracts applied (Table 3). The maximum reduction (37\%) in Chl a content was resulted in seedlings treated with leaf extracts. $C h l b$ content remained unchanged when treating seedlings with root and stem extracts. Compared to the control (distilled water), the leaf and flower extracts resulted in 26 and $14 \%$ reduction in Chl b, respectively. The lowest total chlorophyll content was obtained after treating wild-barley seedlings with leaf extract of A. biebersteinii. Root, stem and flower extracts resulted in almost the same total chlorophyll content.

Protein content was significantly decreased by treating wild-barley seedlings with stem, flower and leaf extracts. The maximum reduction in protein content $(41.7 \%)$ was recorded for leaf extract. Protein content in seedlings treated with root extracts was almost the same as in the control.

\section{DISCUSSION}

The results obtained indicate that water extracts from different parts of $A$. biebersteinii show differential phytotoxic effects on wild barley (Hordeum spontaneum), a weed of economic importance in Mediterranean regions. In the current work, leaf extract inhibited more strongly the seed germination and seedling growth of wild barley than any other extracts (Tables 1 and 2). The degree of phytotoxicity of different $A$. biebersteinii plant parts can be arranged in the following order: leaf $>$ flower $>$ stem $>$ root. This findings can be attributed to the higher concentration of water-soluble allelochemicals in A. biebersteinii leaves than in roots, stems and flowers, or to the variable composition of bioactive phytochemicals between plant tissues.

Several studies have indicated that different parts of the same allelopathic plants might possess different phytotoxic effects on the growth and development of recipient 
plants [14, 37]. In agreement with our results, Hu and Zhang [19] showed that the leaf extract of Chromolaena odorata exerted a more pronounced inhibitory effects on seed germination and seedling growth of different herbaceous species that root extract. In a study exploring the allelopathic properties of Peganum harmala on wild oat and field bindweed, Sodaeizadeh et al. [40] reported that phytotoxic effects of the leaf extracts were higher when compared to root and stem extracts. This is in contrast to the findings of Han et al. [17], who found that ginger stem extracts exhibited greatest inhibition to seed germination and seedling growth of soybean and chive than leaf and rhizome extracts.

All extracts prepared from different parts of $A$. biebersteinii delayed the germination of wild barley. Allelochemicals were reported to delay the germination process possibly by inhibiting enzymatic activities required for seed germination [31,35] and alteration in the activity of gibberellic acid [34].

The present study also revealed that growth of radical of germinated wild-barley seeds and root dry weight of seedlings were found to be more sensitive to all types of A. biebersteinii water extracts in comparison to plumule growth and shoot dry weight. Abu-Romman [3] reported that root growth of pepper seedlings was more susceptible to leaf extracts of $A$. biebersteinii than shoot growth. Similar results with other allelopathic plants have been reported earlier $[4,7,30]$. It is a well-documented fact that root growth is more susceptible to allelochemicals than shoot growth. This might be resulted from the higher permeability of allelochemicals and higher metabolic rate in root compared to shoot tissues $[15,33]$. Ultrastructural changes and tissue browning in root tip were reported after exposure to allelochemicals $[8,13,16]$.

Chlorophyll pigments of wild-barley seedlings were negatively affected by A. biebersteinii water extracts. Reduction in photosynthetic pigments was previously reported as a result of allelochemical stress $[21,38,39]$, which could be resulted from chlorophyll degradation or inhibition of chlorophyll biosynthesis [44, 45].

Shoot protein content of wild barley was significantly reduced due to treatment with stem, flower and leaf extracts. Mersie and Singh [29] documented that allelochemicals resulted in enhanced protein degradation in recipient plant. Moreover, some phenolic acids were reported to inhibit the incorporation of certain amino acid into proteins and thus reduce the rate of protein synthesis [10].

\section{CONCLUSIONS}

In conclusion, the present study conferred that water extracts prepared from different organs of $A$. biebersteinii interfere with germination and growth of wild barley. Maximum inhibitory effects on wild-barley germination and growth were exhibited by leaves and least by roots. The present results suggest that $A$. biebersteinii might be used as a natural herbicide for wild barley control and consequently reduce dependence on synthetic herbicide. 


\section{ACKNOWLEDGEMENTS}

The author is grateful to Aya Awad and Bayan Al-Momany for their technical assistance and sample collection. Work conducted in the author's laboratory is supported by the Scientific Research Deanship of Al-Balqa' Applied University, Scientific Research Fund of the Ministry of Higher Education and Scientific Research, and Abdul Hameed Shoman Foundation.

\section{REFERENCES}

1. Aburjai, M., Hudaib, M. (2006) Antiplatelet, antibacterial and antifungal activities of Achillea falcata extracts and evaluation of volatile oil composition, Pharmacog. Mag. 2, 191-197.

2. Abu-Romman, S. (2011) Comparison of methods for isolating high quality DNA from sage (Salvia officinalis), J. Med. Plants Res. 5, 938-941.

3. Abu-Romman, S. (2011) Allelopathic potential of Achillea biebersteinii Afan. (Asteraceae), World Appl. Sci. J. 15, 947-952.

4. Abu-Romman, S., Ammari, T. (2015) Allelopathic effect of Arundo donax, a mediterranean invasive grass, Plant Omics. 8, 287-291.

5. Alkofahi, A., Batshoun, R., Owais, W., Najib, N. (1996) Biological activity of some Jordanian medicinal plant extracts, Fitoterapia 68, 435-442.

6. Al-Qura'n, S. (2008) Taxonomical and pharmacological survey of therapeutic plants in Jordan, J. Nat. Prod. 1, 10-26.

7. Bader, A., Flamini, G., Cioni, P. L., Morelli, I. (2003) Essential oil composition of Achillea santolina L. and Achillea biebersteinii Afan collected in Jordan, Flavour Fragrance J. 18, 36-38.

8. Bais, H. P., Vepachedu, R., Gilroy, S. (2003) Callaway R. M. and Vivanco J. M., Allelopathy and exotic plant invasion: from molecules and genes to species interactions, Science 301, 1377-1380.

9. Batish, R. D., Lavanya, K., Singh, H. P., Kohli, R. K. (2007) Phenolic allelochemicals released by Chenopodium murale affect the growth, nodulation and macromolecule content in chickpea and pea, J. Plant Growth Regul. 51, 119-128.

10. Baziramakenga, R., Leroux, G. D., Simard, R. R., Nadeau, P. (1997) Allelopathic effects of phenolic acids on nucleic acid and protein levels in soybean seedlings, Can. J. Bot. 75, 445-450.

11. Blum, U., Gerig, T. M., Worsham, A., D. King, L. D. (1993) Modification of allelopathic effects of p-coumaric acid on morning-glory seedling biomass by glucose, methionine, and nitrate, J. Chem. Ecol. 19, 2791-2811.

12. Bradford, M. M. (1976) A rapid and sensitive method for the quantitation of microgram quantities of protein utilizing the principle of protein dye binding, Anal. Biochem. 72, 248-253.

13. Burgos, N. R., Talbert, R. E., Kim, K. S., Kuk, Y. I. (2004) Growth inhibition and root ultrastructure of cucumber seedlings exposed to allelochemicals from rye (Secale cereale), J. Chem. Ecol. 30, 671-689.

14. Chung, I. M., Seigler, D., Miller, D. A., Kyung, S. H. (2000) Autotoxic compounds from fresh alfalfa leaf extracts: identification and biological activity, J. Chem. Ecol. 26, 315-327.

15. Cruz-Ortega, R., Anaya, A. L., Hernández, B. E., Laguna, G. (1998) Effects of allelochemical stress produced by Sicyos deppei on seedling root ultrastructure of Phaseolus vulgaris and Cucurbita ficifolia, J. Chem. Ecol. 24, 2039-2057.

16. Ding, J., Sun, Y., Xiao, C. L., Shi, K., Zhou, Y. H., Yu, J, Q. (2007) Physiological basis of different allelopathic reactions of cucumber and figleaf gourd plants to cinnamic acid, J. Exp. Bot. 58, 37653773.

17. Han, C., M., Pan, K. W., Wu, N., Wang, J. C., Li, W. (2008) Allelopathic effect of ginger on seed germination and seedling growth of soybean and chive, Sci. Hortic. 116, 330-336.

18. Hoagland, L., Carpenter-Boggs, L., Reganold, J. P., Mazzola, M. (2008) Role of native soil biology in Brassicaseous seed meal-induced weed suppression, Soil Biol. Biochem. 40, 1689-1697. 
19. Hu, G., Zhang, Z. (2013) Allelopathic effects of Chromolaena odorata on native and non-native invasive herbs, J. Food Agric. Environ. 11, 878-882.

20. Inderjit, Mallik, A. U. (2002) Can Kalmia angustifolia interference to black spruce (Picea mariana) be explained by allelopathy? Forest Ecol. Manag. 160, 75-84.

21. Jinhu, M., Guofang, X., Wenxiu, Y., Leilei, M., Mei, G., Yuguo, W. (2012) Inhibitory effects of leachate from Eupatorium adenophorum on germination and growth of Amaranthus retroflexus and Chenopodium glaucum, Acta Ecol. Sin. 32, 50-56.

22. Khaliq, A., Matloob, A., Irshad, M. S., Tanveer, A., Zamir, S. I. (2010) Organic weed management in maize (Zea mays L.) through integration of allelopathic crop residues, Pak. J. Weed Sci. Res. 16, $409-420$.

23. Khanh, T. D., Hong, N. H., Xuan, T. D., Chung, I. M. (2005) Paddy weed control by medicinal and leguminous plants from Southeast Asia, Crop Prot. 24, 421-431.

24. Kobayashi, K. (2004) Factors affecting phytotoxic activity of allelochemicals in soil, Weed Biol. Manag. 4, 1-7.

25. Kumari, A., Kohli, R. K. (1987) Autotoxicity of ragweed parthenium (Parthenium hysterophorus), Weed Sci. 35, 629-632.

26. Laterra, P., Bazzalo, M. E. (1999) Seed-to-seed allelopathic effects between two invaders of burned Pampa grasslands, Weed Res. 39, 297-308.

27. Lichtenthaler, H. K. (1987) Chlorophylls and carotenoids: Pigments of photosynthetic biomembranes, Meth. Enzym. 148, 350-382.

28. McIntyre, D. S. (1980) Basic relationships for salinity evaluation from measurements on soil solution, Aust. J. Soil Res. 18, 199-206.

29. Mersie, W., Singh, M. (1993) Phenolic acids affect photosynthesis and protein synthesis by isolated leaf cells of velvet-leaf, J. Chem. Ecol. 19, 1293-1301.

30. Mishra, J. S., Swain, D., Singh, V. P. (2001) Allelopathic effect of Asphodelus tenuifolius on wheat mustard, lentil and chickpea, Pestology. 25, 48-50.

31. Moreno, D, A., Ilic, N., Poulev, A., Brasaemle, D. L., Fried, S., Raskin, I. (2003) Inhibitory effects of grape seed extract on lipases, Nutrition. 19, 876-879.

32. Nekonam, M. S., Razmjoo, J., Kraimmojeni, H., Sharifnabi, B., Amini, H., Bahrami, F. (2014) Assessment of some medicinal plants for their allelopathic potential against redroot pigweed (Amaranthus retroflexus), J. Plant Protect. Res. 54, 90-95.

33. Nishida, N., Tamotsu, S., Nagata, N., Saito, C., Sakai, A. (2005) Allelopathic effects of volatile monoterpenoids produced by Salvia leucophylla: Inhibition of cell proliferation and DNA synthesis in the root apical meristem of Brassica campestris seedlings, J. Chem. Ecol. 31, 1187-1203.

34. Olofsdotter, M. (1998) Allelopathy in rice. In: Olofsdotter, M. (ed.) Proceeding of the workshop on allelopathy in rice, 25-27 Nov. 1996. Manila, Philippines, International Rice Research Institute.

35. Rice, E. L. (1984) Allelopathy. second ed. Academic Press, Orlando, Florida.

36. SAS Institute Inc. (1988) The SAS System for Windows Release 6.12. SAS Institute Inc, Cary, NC.

37. Scrivanti, L. R. (2010) Allelopathic potential of Bothriochloa laguroides var. laguroides (DC.) Herter (Poaceae: Andropogoneae), Flora. 205, 302-305.

38. Siddiqui, Z. S. (2007) Allelopathic effects of black pepper leachings on Vigna mungo (L.) Hepper, Acta Physiol. Plant. 29, 303-308.

39. Siefermann-Harms, D. (1987) The light-harvesting and protective functions of carotenoids in photosynthetic membranes, Physiol. Plant. 69, 561-568.

40. Sodaeizadeh, H., Rafieiolhossaini, M., Havlík, J., Van Damme, P. (2009) Allelopathic activity of different plant parts of Peganum harmala L. and identification of their growth inhibitors substances, Plant Growth Regul. 59, 227-236.

41. Toncer, O., Basbag, S., Karaman, S., Diraz, E., Basbag, M. (2010) Chemical composition of the essential oils of some Achillea species growing wild in Turkey, Int. J. Agric. Biol. 12, 527-530.

42. Weir, T. L., Park, S.-W., Vivanco, J. M. (2004) Biochemical and physiological mechanisms mediated by allelochemicals, Curr. Opin. Plant Biol. 7, 472-479. 
43. Weston, L. A., Duke S. O. (2003) Weed and crop allelopathy. Crit. Rev. Plant Sci. 22, 367-389.

44. Yang, C. M., Lee, C. N., Chou, C. H. (2002) Effects of three allelopathic phenolics on chlorophyll accumulation of rice (Oryza sativa) seedlings: I. Inhibition of supply-orientation, Bot. Bull. Acad. Sin. 43, 299-304.

45. Yang, C. M., Chang, I. F., Lin, S. J., Chou, C. H. (2004) Effects of three allelopathic phenolics on chlorophyll accumulation of rice (Oryza sativa) seedlings: II. Stimulation of consumption-orientation, Bot. Bull. Acad. Sin. 45, 119-125.

46. Zohary, M., Feinbrun-Dothan, N. (1978) In Flora Palaestina, vol. 3. Israel Academy of Sciences and Humanities: Jerusalem. pp. 340-343. 